\title{
Multivariate analysis of 'bacuri' reproductive and vegetative morphology
}

\author{
Isis Gomes de Brito Souza', Valdomiro Aurélio Barbosa de Souza², \\ Kaesel Jackson Damasceno e Silva², Paulo Sarmanho da Costa Lima ${ }^{2}$ \\ 1*Universidade Federal do Piauí, Teresina, PI, Brasi \\ ${ }^{2}$ Empresa Brasileira de Pesquisa Agropecuária - Meio-Norte, Teresina, Pl, Brasil \\ Autor correspondente, e-mail: isisgomesmd@hotmail.com
}

\begin{abstract}
The objective of this study was to characterize sixteen genotypes of $P$. insignis available in the Embrapa Meio-Norte germplasm collection (Teresina, Piauí, Brazil) with respect to 33 morphological traits relating to leaves, flowers, branches, fruits and seeds. Phenotypic variance among genotypes was estimated using the Mahalanobis distance technique and the unweighted pair group method with arithmetic mean analysis (UPGMA). The method of Singh (1981) was used to determine which of the traits contributed most to diversity within genotypes. The occurrence of phenotypic variability among $P$. insignis genotypes indicated that it would be possible to achieve positive gains with selection. The most distant genotypes were BGB 16 and BGB 48, while crosses between genotype BGB 48 and genotypes BGB 32 and BGB 56 offers the greatest potential as parental types for this fruit tree breeding programs. The flesh content, ovary and fruit length, ratio between fruit length and diameter were the characters that most contributed to diversity among the studied genotypes.
\end{abstract}

Keywords: phenotypic diversity, Platonia insignis, Mahalanobis distance

\section{Análise multivariada da morfologia reprodutiva e vegetativa do bacurizeiro}

\section{Resumo}

O objetivo do trabalho foi caracterizar dezesseis genótipos de bacurizeiro disponível na Coleção de Germoplasma da Embrapa Meio-Norte (Teresina, Piauí, Brasil) com base em 33 caracteres relacionados à folha, flor, ramos, fruto e semente. A divergência fenotípica entre os genótipos foi estimada pela distância de Mahalanobis e a análise de agrupamento dos genótipos por meio do método hierárquico da ligação média não ponderada (UPGMA). O método de Singh foi utilizado na determinação de quais caracteres mais contribuem para a diversidade dos genótipos. Observou-se diversidade fenotípica significativa entre os genótipos estudados, indicando que é possível obter ganhos genéticos importantes por meio da seleção. Os genótipos BGB 16 e BGB 48 são os mais divergentes. Entretanto, cruzamentos entre o genótipo 48 e os genótipos BGB 32 e BGB 56 oferecem potencial como parentais em programas de melhoramento da frutífera. $O$ teor de polpa, comprimento do fruto, comprimento do ovário e relação comprimento / diâmetro do fruto são os caracteres que mais contribuem para a diversidade entre os genótipos estudados.

Palavras-chave: diversidade fenotípica, Distância de Mahalanobis, Platonia insignis 


\section{Introduction}

Platonia insignis Mart., commonly known as 'Bacurizeiro', is a native fruit tree from the Amazon region where it presents rich variability in a number of characteristics of interest, including the size and shape of the fruit, and the quality and yield of the flesh (Cavalcante, 1996). Despite its high potential and food value, scientific knowledge about $P$. insignis is limited in respect of most of the aspects that are essential to the successful cultivation of the species. Thus, basic information regarding the floral biology, reproductive mechanisms, cultural management, minimum descriptors and genetic diversity is sparse.

Detailed understanding of the genetic variability within a species is important in directing crosses aiming the production of segregating populations that could be valuable in the selection of new varieties. Indeed, plant improvement programs rely on information concerning the diversity of native populations, and on the full characterization and subsequent conservation of indigenous varieties (Rodrigues et al., 2008). In relation to P. insignis, only a small number of studies have focused on genotypic and phenotypic characterization, the most recent being Souza et al. (2013) and Silva et al. (2009).

Morphological characterization is essential in building the description of a species and for developing a germplasm management, while multivariate statistical analysis is useful for screening the genotypes of a collection and evaluate the contribution of individual characters. Application of Mahalanobis distance as a measure of dissimilarity, and the unweighted pair group method with arithmetic mean (UPGMA) system for hierarchical clustering, represent efficient multivariate techniques frequently used to determine phenotypic diversity. These methods have been used in the phenotypic analysis of various fruit tree species, including Plinia cauliflora (Danner et al., 2010), Nephelium lappaceum (Andrade et al., 2011) and Pyrus communis L. (Pereira-Lorenzo et al., 2012).

The objective of this study was to characterize the phenotypic diversity of sixteen genotypes of bacuri tree maintained in the germplasm collection of Embrapa Meio-Norte and determining which of the analyzed traits best discriminates the genotypes.

\section{Material and methods}

Plant material

Sixteen genotypes of $P$. insignis were available in the germplasm collection of Embrapa Meio-Norte (Teresina, Piauí, Brazil; latitude 505's, longitude $42^{\circ} 49^{\prime} \mathrm{W}$ and $72 \mathrm{~m}$ of altitude, above sea level) during the 2009 reproductive period , collecting 8 genotypes from different areas in the Piauí State (PI) and 8from different sites in the State of Maranhão (MA) (Table 1).

Table 1. Geographical origin of the studied 16 genotypes of Platonia insignis Mart.

\begin{tabular}{lcc}
\hline \multicolumn{1}{c}{ Genotype } & Code & Location \\
\hline M5MP16 F4 PL9 & BGB 61 & Carolina, Maranhão \\
Clonal 3 & BGB 66 & Carolina, Maranhão \\
M3MP1 F13 PL5 & BGB 36 & Caxias, Maranhão \\
M5MP1 F14 PL5 & BGB 38 & Caxias, Maranhão \\
Clonal & BGB 58 & Passagem Franca, Maranhão \\
Gema de ovo & BGB 56 & Passagem Franca, Maranhão \\
M121PE F16 PL5 & BGB 48 & Santa Quitéria do Maranhão, Maranhão \\
CEMI F8 PL2 & BGB 32 & Timon, Maranhão \\
M4PP5 F8 PL8 & BGB 6 & Barras, Piauí \\
M6PP5 F13 PL4 & BGB 7 & Barras, Piauí \\
M7PP5 F15 PL5 & BGB 8 & Barras, Piauí \\
M9PP5 F7 PL2 & BGB 10 & Barras, Piauí \\
M11PP5 F13 PL11 & BGB 11 & Barras, Piauí \\
M16PP5 F10 PL10 & BGB 15 16 Barras, Piauí \\
M17PP5 F8 PL9 & BGB 16 & Barras, Piauí \\
M8PP2 F11 PL10 & BGB 3 & Palmeirais, Piauí \\
\hline
\end{tabular}


Characterization of genotypes

Genotypic characterization was based on 33 traits relating to the leaves, branches, flowers, fruits and seeds taken from plants of each of the studied genotypes. Each genotype was represented by one plant. The characters were: a) Leaf trait: petiole length (LPI), leaf blade length (LLB), leaf blade width (WLB), and LLB/WLB ratio, where the measurements were performed on 10 leaves per genotype, each located between the first and second internodes of branches from the median portion of the plant; b) branch trait: length of internode section (LIS) where the distance between the first and second internodes were performed on 10 branches per genotype; c) Flower trait: flower length (LFR), flower diameter (DFR), pedicel length (LPD), combined pedicel and flower length (LPD+LFR), petal length (LPT), petal width (WPT), LPT/WPT ratio, ovary length (LOV), ovary diameter (DOV), LOV/DOV ratio, length of style (LSL), difference in stigma height in relation to anther (HSG), average length of filaments (LFL) and average number of filaments per stamen (NFL). Measurements were performed on 10 flowers per genotype during full blooming; d) Fruit traits: fruit length (LFT), fruit diameter (DFT), LFT/DFT ratio, fruit mass (MFT), skin thickness (TSK), skin mass (MSK), flesh mass (MPU), flesh content (CPU; CPU = MPU/MFT), number of parthenocarpic sections (NPS), total titratable acidity (TTA), total soluble solids (TSS) and TSS/ TTA ratio. Measurements were performed on 10 mature fruits per genotype; e) Seed traits: mass of seeds per fruit (MSS) and number of seeds per fruit (NSS). Measurements were performed on seeds from all evaluated fruit.

Mass measurements were performed using a high precision balance and expressed in grams (g). Length, width, thickness and diameter were obtained using a digital caliper and expressed in $\mathrm{mm}$. Values of TSS were determined using a digital bench-top refractometer 10 $32 \%)$ with automatic temperature correction, while TTA values were determined according to $\square \square$ Instituto Adolfo Lutz (2008) protocol and expressed as percentage of citric acid. All data were standardized before analysis.

Statistical analysis
The Mahalanobis distance was employed as a measure of dissimilarity between all genotype pairs, and the results presented as a matrix. The relative contribution of the studied traits to variability among genotypes was evaluated using the method of Singh (1981). In order to visualize the clustering structure, a dendrogram was constructed based on the UPGMA algorithm with the mean dissimilarity level of all studied pairs (0.20) taken as the cut-off point. The analysis were performed with the aid of GENES software (Cruz, 2006).

\section{Results}

Analysis of dissimilarity

The phenetic distances between the genotype pairs varied in the range of 45.07 [between BGB 3 (Palmeirais, PI) and BGB 36 (Caxias, MA)] to 396.77 [between BGB 48 (Santa Quitéria do Maranhão, MA) and BGB 16 (Barras, $\mathrm{PI})$ ], and the mean value was 143.43 (Table 2). Interestingly, genotype BGB 48 was not the only of the pair presenting the greatest diversity in the germplasm collection, but was also involved in the vast majority of combinations presenting high levels of diversity.

\section{Contribution of traits}

The traits that most contributed to divergence (Singh, 1981) within the 16 genotypes of $P$. insignis studied were flesh content (17.00\%), ratio between fruit length and diameter (12.40\%), fruit length (11.46\%) and petal width (7.85\%). Together, these traits were responsible for $48.71 \%$ of the total variability. Conversely, the traits that contributed least to genotypic diversity were ratio between leaf blade length and width $(0.24 \%)$, ratio between total soluble solids and total titratable acidity $(0.28 \%)$ and leaf blade width $(0.35 \%)$ (Table 3).

\section{UPGMA analysis}

The UPGMA dendrogram (Figure 1) showed five distinct groups, two presenting moderate levels of dissimilarity and three isolated genotypes. There is no identical genotypes among the 16 samples. The most distant genotypes were BGB 16 and BGB 48, while BGB 


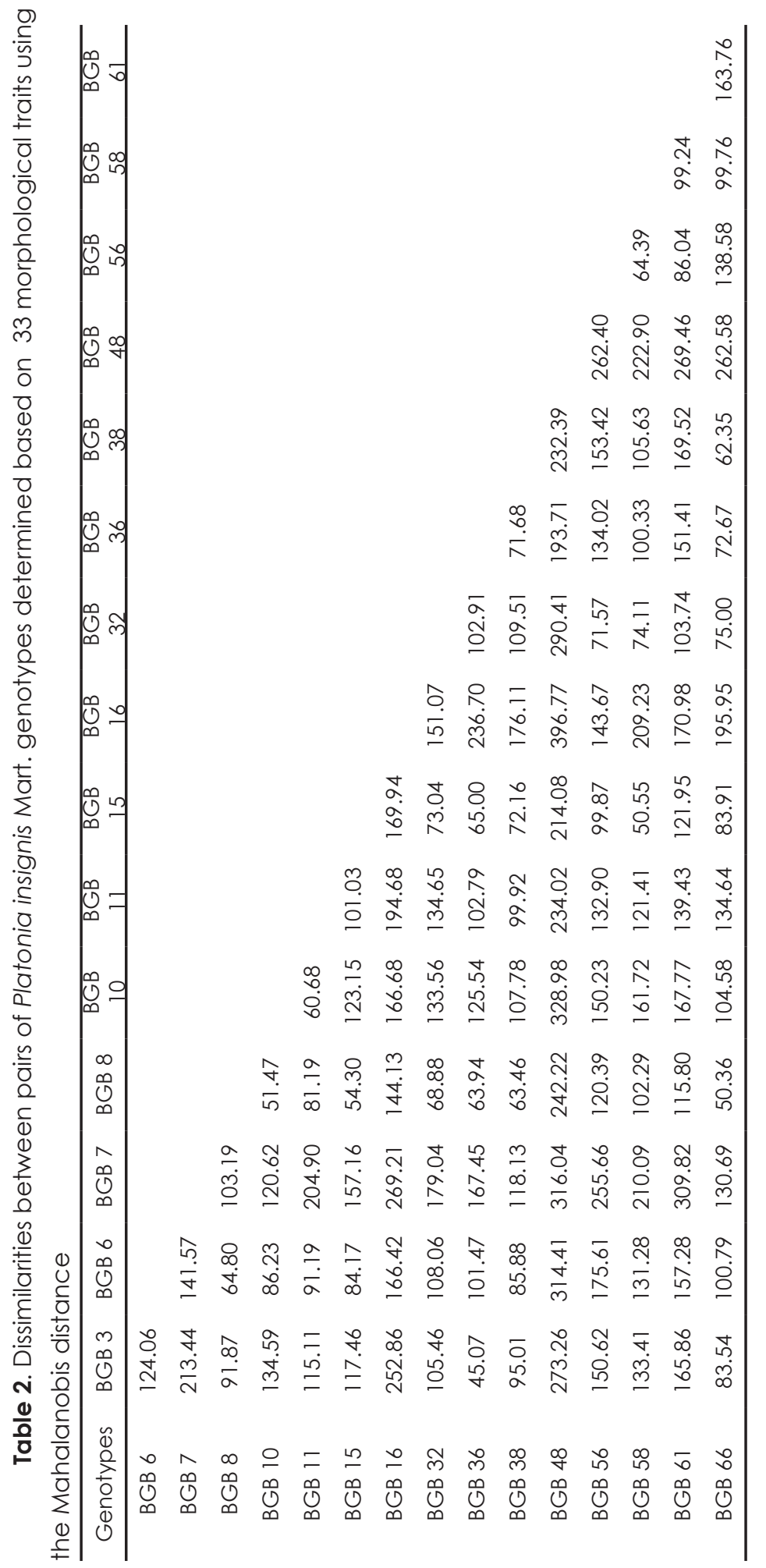


Table 3. Relative contribution of morphological traits to the genetic divergence of Platonia insignis Mart. genotypes (based on the statistical method proposed by Singh, 1981)

\begin{tabular}{|c|c|c|}
\hline Trait & Organ & $\frac{\text { Relative contribution }}{\%}$ \\
\hline Height of stigma in relation to anthers (HSG) & Flower & 1.3875 \\
\hline Style length (LSL) & & 5.4892 \\
\hline Average length of filaments (LFL) & & 2.5878 \\
\hline Average number of filaments per stamen (NFL) & & 3.4761 \\
\hline Petal length (LPT) & & 5.4161 \\
\hline Petal width (WPT) & & 7.8569 \\
\hline Ratio LPT/WPT & & 4.1738 \\
\hline Pedicel length (LPD) & & 0.8253 \\
\hline Flower length (LFR) & & 2.0390 \\
\hline Combined LPD + LFR & & 1.6954 \\
\hline Flower diameter (DFR) & & 1.1586 \\
\hline Ovary length (LOV) & & 5.1172 \\
\hline Ovary diameter (DOV) & & 0.9100 \\
\hline Ratio LOV/DOV & & 1.4987 \\
\hline Leaf blade width (WLB) & Leaf & 0.3592 \\
\hline Leaf blade length (LLB) & & 0.3940 \\
\hline Ratio LLB/WLB & & 0.2412 \\
\hline Petiole length (LPI) & & 0.4172 \\
\hline Length of internode section (LIS) & Branch & 0.4707 \\
\hline Fruit diameter (DFT) & Fruit & 0.4720 \\
\hline Fruit length (LFT) & & 11.4649 \\
\hline Ratio LFT/DFT & & 12.4045 \\
\hline Mass of fruit (MFT) & & 4.1522 \\
\hline Skin thickness (TSK) & & 0.5409 \\
\hline Skin mass (MSK) & & 1.9590 \\
\hline Flesh mass (MPU) & & 0.4900 \\
\hline Number of parthenocarpic sections (NPS) & & 0.4007 \\
\hline Flesh content (CPU) & & 17.0099 \\
\hline Total titratable acidity (TTA) & & 0.4263 \\
\hline Total soluble solids (TSS) & & 0.6212 \\
\hline Ratio TSS/TTA & & 0.2866 \\
\hline Mass of seeds per fruit (MSS) & Seed & 1.7665 \\
\hline Number of seeds per fruit (NSS) & & 2.4910 \\
\hline
\end{tabular}

3 and BGB 36 presented the closest similarity of the entire collection, followed by BGB 8 and BGB 32. Group C2 comprised the largest number of genotypes $(11 ; 68.75 \%)$, and these originated from the municipalities of Barras, PI (BGB 6, BGB 8, BGB 10, BGB 11 and BGB 15), Caxias, MA (BGB 36 and $B G B$ 38), Passagem Franca, $M A$ (BGB 58), Carolina, $M A$ (BGB 66), Palmeirais, $\mathrm{PI}$ (BGB 3) and Timon, $M A$ (BGB 32). The remaining groups are comprised by only one genotype each, with the exception of Group C3, which contained BGB 56 (Passagem Franca, MA) and BGB 61 (Carolina, MA).

Group C2 incorporated genotypes that produced fruits with the largest mass (high MFT values), thus offering obvious potential in a plant breedingprogram. Within Group C3, the genotypes BGB 56 and BGB 61 produce fruit with a high flesh content (high CPU value), which would be advantageous for breeding programs that aim to perpetuate this trait. The single genotype of Group Cl (BGB 48; Santa Quitéria do Maranhão, MA) produces flowers with stigmas that are elongated with respect to the anthers (high HSG value), and this could facilitate the process of pollination. Fruit of the Group C4 genotype (BGB 7; Barras, PI) are unusual in that they have no seeds (low NSS values) and contain 
only parthenocarpic sections (high NPS values). in industry. The genotype of Group C5 (BGB 16; Unfortunately, the fruits from this genotype Barras, $\mathrm{PI}$ ) produces fruit with high total soluble are relatively small and the flesh is hard and solids (high TSS values) and, thus, could constitute unsuitable for in natura consumption or for use a good parental type (Table 4).

Dissimilarity level

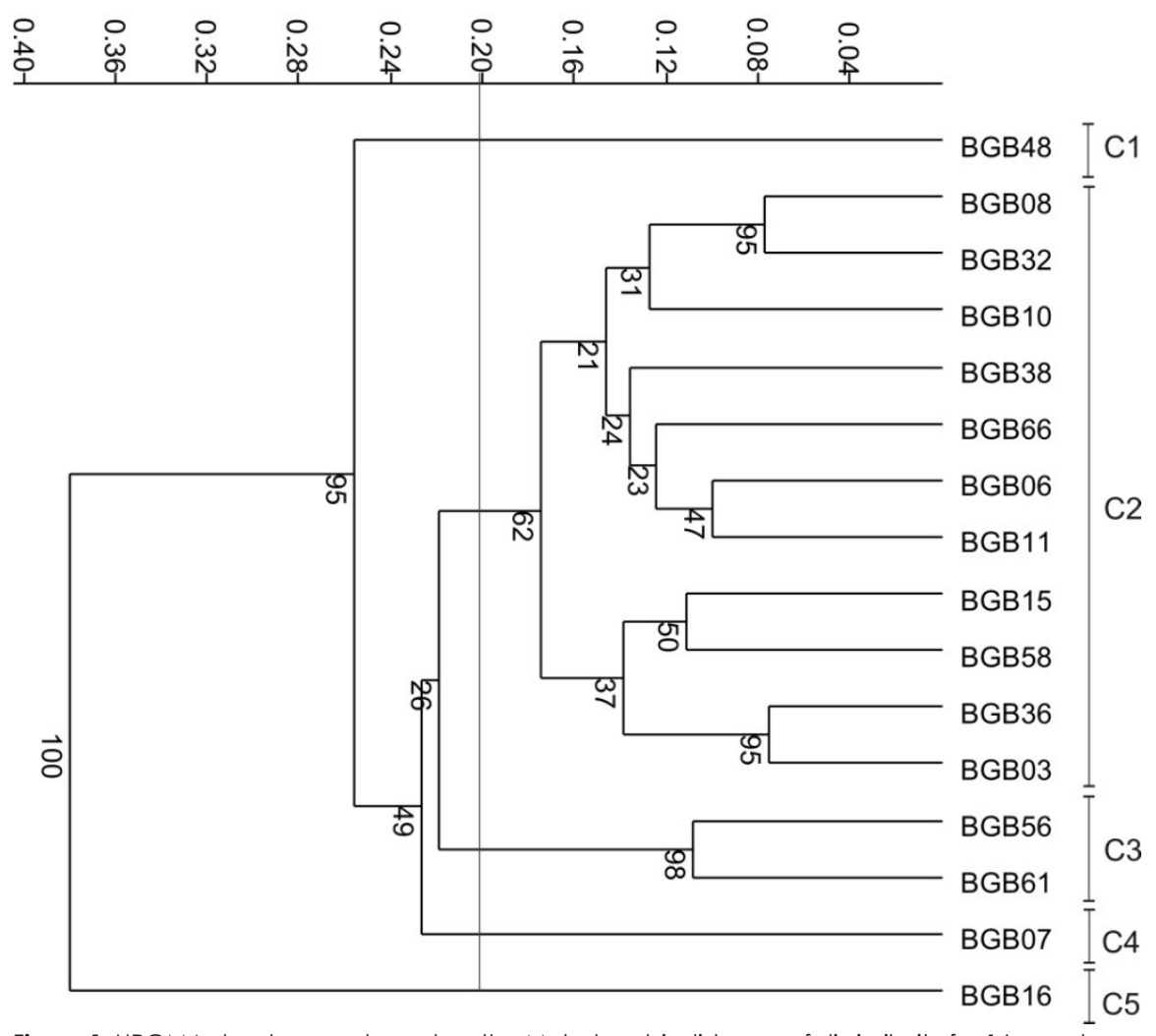

Figure 1. UPGMA dendrogram based on the Mahalanobis distance of dissimilarity for 16 genotypes of Platonia insignis Mart. maintained in the germplasm collection of Embrapa Meio-Norte (Teresina, $\mathrm{Pl}$, Brazil) using 33 morphological traits. Bootstrap values are shown below the nodes.

Table 4. Mean values for 33 morphological traits of the 16 studied Platonia insignis Mart. genotypes.

\begin{tabular}{ccccccccccccc}
\hline Genotype & $\begin{array}{c}\text { HSG } \\
\mathrm{mm}\end{array}$ & $\begin{array}{c}\mathrm{LSL} \\
\mathrm{mm}\end{array}$ & $\begin{array}{c}\mathrm{LFL} \\
\mathrm{mm}\end{array}$ & $\mathrm{NFL}$ & $\begin{array}{c}\text { LPT } \\
\mathrm{mm}\end{array}$ & $\begin{array}{c}\text { WPT } \\
\mathrm{mm}\end{array}$ & $\begin{array}{c}\text { LPT/ } \\
\text { WPT }\end{array}$ & $\begin{array}{c}\text { LPD } \\
\mathrm{mm}\end{array}$ & $\begin{array}{c}\text { LFR } \\
\mathrm{mm}\end{array}$ & $\begin{array}{c}\text { LPD+LFR } \\
\mathrm{mm}\end{array}$ & $\begin{array}{c}\text { DFR } \\
\mathrm{mm}\end{array}$ & $\begin{array}{c}\text { LOV } \\
\mathrm{mm}\end{array}$ \\
\hline BGB 3 & 5.95 & 26.66 & 45.00 & 80.45 & 44.16 & 44.88 & 0.99 & 36.33 & 61.19 & 96.04 & 46.65 & 13.53 \\
BGB 6 & 2.38 & 22.78 & 43.11 & 90.90 & 34.44 & 43.37 & 0.79 & 25.83 & 56.18 & 75.34 & 46.41 & 15.79 \\
BGB 7 & 4.69 & 19.46 & 43.54 & 52.75 & 36.34 & 43.41 & 0.84 & 31.47 & 55.46 & 82.23 & 39.47 & 20.74 \\
BGB 8 & 2.90 & 21.77 & 40.98 & 59.00 & 38.53 & 41.78 & 0.92 & 27.38 & 53.62 & 77.49 & 41.77 & 14.40 \\
BGB 10 & 6.77 & 24.55 & 34.57 & 56.00 & 35.95 & 38.75 & 0.94 & 35.23 & 50.79 & 80.96 & 42.51 & 17.06 \\
BGB 11 & 7.59 & 30.05 & 38.88 & 86.30 & 38.32 & 36.93 & 1.04 & 31.82 & 52.79 & 84.61 & 40.90 & 14.83 \\
BGB 15 & 8.13 & 28.22 & 40.23 & 83.95 & 36.57 & 40.66 & 0.90 & 29.28 & 57.05 & 82.84 & 41.98 & 14.07 \\
BGB 16 & 9.21 & 19.50 & 28.38 & 85.45 & 25.92 & 37.34 & 0.70 & 21.58 & 42.18 & 62.05 & 35.34 & 9.61 \\
BGB 32 & 2.06 & 23.56 & 40.10 & 64.70 & 36.59 & 40.92 & 0.90 & 31.79 & 52.06 & 78.44 & 42.60 & 14.19 \\
BGB 36 & 5.70 & 26.74 & 43.96 & 74.60 & 43.99 & 44.78 & 0.98 & 34.62 & 58.96 & 90.35 & 41.94 & 13.43 \\
BGB 38 & 8.55 & 22.24 & 40.65 & 104.85 & 38.90 & 44.47 & 0.88 & 29.93 & 58.57 & 86.71 & 45.24 & 14.98 \\
BGB 48 & 11.13 & 31.77 & 45.15 & 99.95 & 43.21 & 43.49 & 1.00 & 22.99 & 65.03 & 86.23 & 44.08 & 16.65 \\
BGB 56 & 6.12 & 32.38 & 35.10 & 57.90 & 34.15 & 37.40 & 0.92 & 28.46 & 49.36 & 77.83 & 38.82 & 12.05 \\
BGB 58 & 4.06 & 33.12 & 44.72 & 85.95 & 41.61 & 43.70 & 0.96 & 29.15 & 59.79 & 91.46 & 45.82 & 19.29 \\
BGB 61 & 6.27 & 30.20 & 35.82 & 60.20 & 38.85 & 37.21 & 1.05 & 21.53 & 50.30 & 68.99 & 41.20 & 14.62 \\
BGB 66 & 3.61 & 21.27 & 39.02 & 68.05 & 40.17 & 47.91 & 0.84 & 29.65 & 54.31 & 79.99 & 49.72 & 18.31 \\
\hline
\end{tabular}
continue... 
Table 4. Mean values for 33 morphological traits of the 16 studied Platonia insignis Mart. genotypes.

\begin{tabular}{cccccccccccc}
\hline Genotype & $\begin{array}{c}\text { DOV } \\
\mathrm{mm}\end{array}$ & $\begin{array}{c}\text { LOV/ } \\
\text { DOV }\end{array}$ & $\begin{array}{c}\text { LIS } \\
\mathrm{mm}\end{array}$ & $\begin{array}{c}\text { WLB } \\
\mathrm{mm}\end{array}$ & $\begin{array}{c}\text { LLB } \\
\mathrm{mm}\end{array}$ & $\begin{array}{c}\text { LLB/ } \\
\text { WLB }\end{array}$ & $\begin{array}{c}\text { LPI } \\
\mathrm{mm}\end{array}$ & $\begin{array}{c}\text { LLB } \\
\mathrm{mm}\end{array}$ & $\begin{array}{c}\text { LLB/ } \\
\text { WLB }\end{array}$ & $\begin{array}{c}\text { LPI } \\
\mathrm{mm}\end{array}$ & $\begin{array}{c}\text { DFT } \\
\text { Mm }\end{array}$ \\
\hline BGB 3 & 10.54 & 1.29 & 111.20 & 119.40 & 43.20 & 2.77 & 15.20 & 43.20 & 2.77 & 15.20 & 105.25 \\
BGB 6 & 12.01 & 1.32 & 92.00 & 78.60 & 42.80 & 1.84 & 11.80 & 42.80 & 1.84 & 11.80 & 136.40 \\
BGB 7 & 14.99 & 1.38 & 116.40 & 72.40 & 38.00 & 1.90 & 11.00 & 38.00 & 1.90 & 11.00 & 81.00 \\
BGB 8 & 12.71 & 1.13 & 122.00 & 99.00 & 42.00 & 2.41 & 9.20 & 42.00 & 2.41 & 9.20 & 105.70 \\
BGB 10 & 13.39 & 1.28 & 110.00 & 112.00 & 50.00 & 2.24 & 10.00 & 50.00 & 2.24 & 10.00 & 125.20 \\
BGB 11 & 12.57 & 1.24 & 91.40 & 92.80 & 44.40 & 2.13 & 10.20 & 44.40 & 2.13 & 10.20 & 141.80 \\
BGB 15 & 10.36 & 1.36 & 55.10 & 81.10 & 35.30 & 2.29 & 10.80 & 35.30 & 2.29 & 10.80 & 95.78 \\
BGB 16 & 9.44 & 1.02 & 95.00 & 80.60 & 49.80 & 1.64 & 10.60 & 49.80 & 1.64 & 10.60 & 92.93 \\
BGB 32 & 11.69 & 1.23 & 107.00 & 87.00 & 34.00 & 2.56 & 10.40 & 34.00 & 2.56 & 10.40 & 75.74 \\
BGB 36 & 10.64 & 1.27 & 72.00 & 88.60 & 37.60 & 2.36 & 11.80 & 37.60 & 2.36 & 11.80 & 112.90 \\
BGB 38 & 14.87 & 1.01 & 109.00 & 82.40 & 41.80 & 1.99 & 9.00 & 41.80 & 1.99 & 9.00 & 101.00 \\
BGB 48 & 12.30 & 1.35 & 74.20 & 80.80 & 41.80 & 1.94 & 9.00 & 41.80 & 1.94 & 9.00 & 105.63 \\
BGB 56 & 9.98 & 1.22 & 81.57 & 78.98 & 38.90 & 2.08 & 10.30 & 38.90 & 2.08 & 10.30 & 78.49 \\
BGB 58 & 12.13 & 1.60 & 69.00 & 84.20 & 38.80 & 2.19 & 10.00 & 38.80 & 2.19 & 10.00 & 88.45 \\
BGB 61 & 9.74 & 1.50 & 218.00 & 86.00 & 47.00 & 1.84 & 8.80 & 47.00 & 1.84 & 8.80 & 103.49 \\
BGB 66 & 14.05 & 1.30 & 105.00 & 95.60 & 41.40 & 2.32 & 13.20 & 41.40 & 2.32 & 13.20 & 97.00 \\
\hline C0ntin 490 & & & & & & & & & &
\end{tabular}

Table 4. Mean values for 33 morphological traits of the 16 studied Platonia insignis Mart. genotypes.

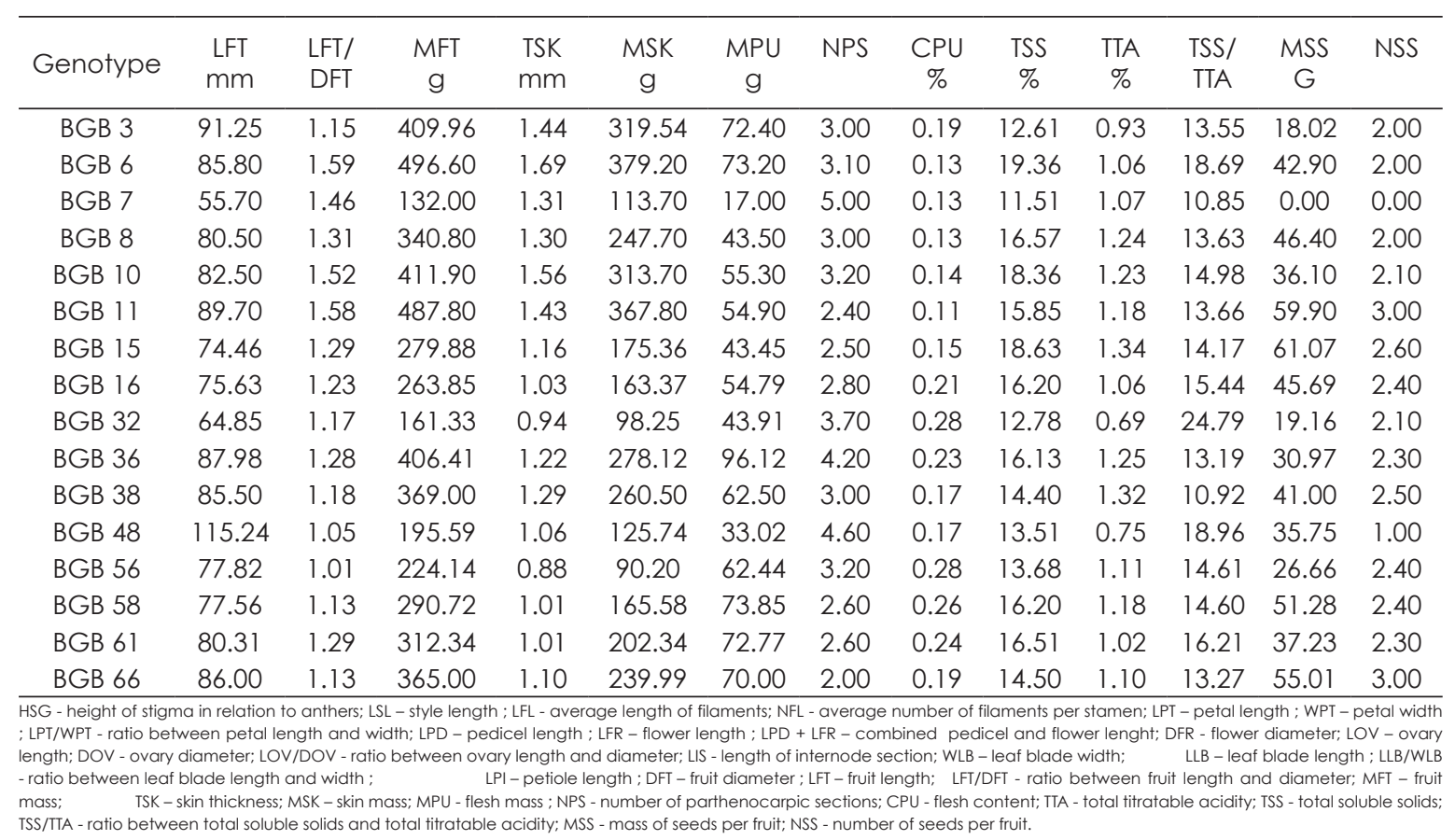




\section{Discussion}

In the Embrapa Meio-Norte germplasm collection, $32 \%$ of the genotypic pairs of $P$. insignis showed dissimilarities that were equivalent to or larger than the overall mean (143.43), indicating that the genetic divergence in the most of the collection was not substantial. This result may be due to $P$. insignis be incipiently domesticated. Also, germplasm collections are generally formed with sampling from apparently interesting fruit for further genetic improvement that are expected to be more uniform than a wild collection.

BGB 48 was included in many of the most divergent combinations evaluated suggesting that this genotype could provide an acceptable heterotic effect when employed as a parent in hybridization programs (Table 2). Furthermore, this genotype produces fruit with a high pulp content and an elevated concentration of total soluble solids (high CPU and TSS values; Table 4), characteristics that are desired by the processing industry.

Considering that parental types exhibiting the largest divergence for the greatest potential to generate progeny populations with wide variability and potent heterotic effects, the most promising hybridizations would be those involving combinations of genotypes with high genetic dissimilarity indices. However, in order to reduce the number of hybridizations, the selection of possible parents should be based not only on estimates of dissimilarity but also on combinations that aggregate the maximum number of desirable agronomical traits (Rimoldi et al, 2010). Indeed, diallelic crossing is one of the tools that can be employed for the best genotypes (Lima and Cardoso, 2000).

The five groups obtained using the UPGMA method (Figure 1) confirmed the presence of variability in the germplasm studied as previously indicated by dissimilarities indices (Table 2). The identification of genotypic groups hasparticular importance since controlled crosses involving genotypes from different groups can generate greater heterosis in the resulting hybrids (Missio et al., 2007). Moreover, the number of different groups identified highlights the moderate variability among the genotypes studied. In the case of $V$. vinifera, for example,
Leão et al. (2011) used the UPGMA method to evaluate the morphological characteristics of 136 genotypes maintained in the germplasm collection of Embrapa Semi-Árido, and the autors were able to identify 30 different groups.

In the present study, although it would be possible to carry out numerous crosses involving members of the five genotypic groups identified (three of which contained only one genotype), it is important to stress that appropriate combinations would be those that maximized the number of desirable traits. The significant contributions of the variables CPU and LFT/DFT to the genetic divergence (Singh, 1981) observed in $P$. insignis demonstrates that such traits are important in the characterization process. Indeed, these two traits may be used as good descriptors in future studies to characterize the species. On the other hand, LLB/WLB, TSS/TTA and WLB contributed little to the variability observed and their use in future characterization studies is not justified. Following studies involving 18 morphological descriptors for syagrus oleracea (Mart.) Becc. (guarirobeira), an indigenous fruit tree from the Brazilian cerrado, Pinto et al. (2010) concluded that it was possible to discard $55 \%$ of the traits without loss of information.

The presented results suggested that variations in morphological traits may be used in the characterization of germplasm genotypes and can be useful as an inexpensive tool in the management of a germplasm collection. The results of the multivariate analysis of 16 genotypes of $P$. insignis suggested that crosses between genotype BGB 48 and genotypes $\mathrm{B} \square \mathrm{GB}$ 6, BGB 7, BGB 10 and BGB 16 may have potential for the production of segregating populations to be employed in genetic studies and plant improvement. However, if the desirable trait is CPU, as would be the case for plants to be exploited by the flesh processing industry, the most suitable crosses would be between BGB 48 and $B G B 32$ or BGB 56 genotypes, since this combination aggregates advantageous characters (Rimoldi et al, 2010).

\section{Conclusion}

1. There is moderate variability among the $P$. insignis genotypes maintained in the 
Embrapa Meio-Norte germplasm collection.

2. Genotypes BGB 16 and BGB 48 showed the highest degree of divergence within the collection.

3. Genotypes BGB 48 and BGB 32 or BGB 56 offers the greatest potential as parental types for breeding programs of this fruit tree.

4. The characters that most contributed to diversity among the genotypes studied were flesh content, fruit length and ratio between fruit length and diameter.

\section{Acknowledgements}

The authors wish to thank the 'Fundo de Desenvolvimento Científico e Tecnológico' (FUNDECI) of 'Banco do Nordeste' -BNB for providing funding to the present study.

\section{References}

Andrade, R.A $\square$., Wickert, E., Martins, A.B.G., Andrade, M.M.C., Lemos, E.G.M. 2011. Diversidade genética de acessos de Nephelium lappaceum L. através de caracterização morfológica e molecular. Comunicata Scientiae 2: 91-99.

Cavalcante, P.B. 1996. Frutas Comestíveis da Amazônia, sixth ed. Museu Paraense Emílio Goeldi, Belém, Brazil. 279p.

Cruz, C.D. 2006. Programa Genes: aplicativo computacional em genética e estatística versão Windows. UFV, Viçosa, Brasil. CD-ROM.

Danner, M.A., Citadin, I., Sasso, S.A.Z., Scariot, S., Benin, G. 2011. Genetic dissimilarity among jabuticaba trees native to southwestern Paraná Brazil. Revista Brasileira de Fruticultura 33: 517-525.

Instituto Adolfo Lutz. Métodos Físico-químicos para Análise de Alimentos, fourth ed. Instituto Adolfo Lutz, São Paulo, SP, Brazil, 2008. http://www.crq4. org.br/sms/files/file/analisedealimentosial_2008. pdf/ <Accessed in 24 Jan 2013>

Leão, P.C.S., Cruz, C.D., Motoike, S.Y. 2011. Genetic diversity of table grape based on morphoagronomic traits. Scientia Agrícola 68: 42-49.

Lima, A.T.S., Cardoso, A.I.I. 2012. Produção e heterose de híbridos experimentais

de pepino do tipo japonês. Revista Ceres 59: 484492.

Missio, R.F., Moraes, M.L.T., Dias, L.A.S. 2007. Efeito do desbaste seletivo sobre a divergência genética em progênies de Pinus caribaea
Morelet var. bahamensis. Scientia Forestalis 73 : 27-36.

Pereira-Lorenzo, S., Santos, A.R.F., RamosCabrer, A.M., Sal F., Díaz-Hernández, M.B. 2012. Morphological variation in local pears from northwestern Spain. Scientia Horticulturae 138:176-182.

Pinto, J.F.N., Reis, E.F., Faleiro, F.G., Barbosa, E.C.C., NUNES, H.F. 2010. Seleção de descritores vegetativos para caracterização de acessos de guariroba (Syagrus oleracea (Mart.) Becc.). Revista Brasileira de Fruticultura 32: 832-840.

Rimoldi, F., Vidigal Filho, P.S., Kvitschal, M.V., Gonçalves-Vidigal, M.C., Prioli, A.J., Prioli, S.M.S.P., Costa, T.R. 2010. Genetic divergence in sweet cassava cultivars using morphological agronomic traits and RAPD molecular markers. Brazilian Archives of Biology and Technology 53: 1477-1486.

Rodrigues, L.C., Morales, M.R., Fernandes, A.J.B., Ortiz, J.M. 2008. Morphological characterization of sweet and sour cherry cultivars in a germplasm bank at Portugal. Genetic Resources and Crop Evolution 55: 593-60.

Silva, R.G., Chaves, M.C.L., Arnhold, E., Cruz, C.D. 2009. Repetibilidade e correlações fenotípicas de caracteres do fruto de bacuri no Estado do Maranhão. Acta Scientiarum. Agronomy 31: 587591.

Singh, D. 1981. The relative importance of characters affecting genetic divergence. The Indian Journal of Genetics and Plant Breeding 41: 237-245.

Souza, I.G.B., Souza, V.A.B., Lima, P.S.C. 2013. Molecular characterization of Platonia insignis Mart. ("Bacurizeiro") using inter simple sequence repeat (ISSR) Markers. Molecular Biology Reports 40: 3835-3845. 